\title{
Quality of life in individuals with spinocerebellar ataxia type 10: a preliminary study
}

Qualidade de vida em indivíduos com ataxia espinocerebelar tipo 10: estudo preliminar

Laudiane Reis Santos ${ }^{1}$, Hélio Afonso Ghizoni Teive², Francisco Diego Negrão Lopes Neto ${ }^{3}$, Ana Carolina

Brandt de Macedo ${ }^{4}$, Neliana Maria de Mello5, Marise Bueno Zonta ${ }^{1,5}$

\begin{abstract}
Spinocerebellar ataxia type 10 (SCA10) is characterized by gait ataxia, dysarthria, nystagmus, epilepsy, reduced cognitive ability and depression, which lead to functional loss and behavioral changes. These signs gradually evolve and may interfere with the physical, emotional, and social aspects of quality of life (QoL). Objective: To assess the self-perception of quality of life and its association with disease duration, severity of ataxia, balance and functional independence. Methods: This study focused on the disease duration, ataxia severity (SARA), balance (Berg Balance Scale), functionality (FIM, Lawton IADL) and QoL (SF-36 v.2) of 15 individuals with SCA10. Results: The population sample consisted of eight females and seven males, with a mean age of 43.8 ( \pm 8.2) years, mean age of symptom onset of 33.1 ( \pm 8.9) years and mean disease duration of 9.8 ( \pm 11.2) years. The mean Berg Balance Scale score was 47.2 ( \pm 12 ), mean SARA score $(n=14) 11.5$ ( \pm 7.3), mean Lawton IADL score 20.4 ( \pm 1.8) and mean FIM score $120.3( \pm 5.4)$. Individuals with SCA10 had a greater impairment of QoL in the "role-physical" domain ( $p=0.04)$. The longer the disease duration $(p=0.02)$, risk of falling $(p=0.04)$, severity of ataxia $(p=0.00)$ and functional dependence in activities of daily living $(p=0.03)$ and instrumental activities of daily living $(p=0.00)$, the worse the QoL was in the "physical functioning" domain, with a decrease of 1.62 points for each year of disease duration. Conclusion: In this sample, the greatest impairment of QoL in individuals with SCA10 was observed in "physical functioning" and "physical role".
\end{abstract}

Keywords: spinocerebellar ataxias; quality of life; surveys and questionnaires.

\section{RESUMO}

A Ataxia Espinocerebelar tipo 10 (SCA10) caracteriza-se pela ataxia da marcha, disartria, nistagmo, epilepsia, redução da capacidade cognitiva e depressão, causando perda funcional e alterações comportamentais. Esses sinais evoluem gradualmente e podem interferir nos aspectos físicos, emocionais e sociais da Qualidade de Vida (QV). Objetivo: Avaliar a autopercepção da qualidade de vida e sua associação com a duração da doença, gravidade da ataxia, equilíbrio e independência funcional. Método: 0 estudo enfoca a duração da doença, gravidade da ataxia (SARA), equilíbrio (EEB), funcionalidade (MIF, Lawton) e QV (SF-36 v.2) de 15 indivíduos com SCA10. Resultados: A amostra foi composta por oito indivíduos do sexo feminino, com média de idade de 43,8 ( \pm 8,2), de idade de início dos sintomas 33,1 ( \pm 8,9) e de tempo de doença de $9,8( \pm 11,2)$ anos. A média do escore na Berg foi 47,2 ( $\pm 12,0)$, no SARA $(n=14)$ foi de $11,5( \pm 7,3)$, na escala de LAWTON 20,4 ( $\pm 1,8)$ e na MIF 120,3 ( \pm 5,4) pontos. Os Indivíduos com SCA10 apresentaram maior prejuízo na QV no domínio "Aspectos Físicos" ( $p=0,04)$. Quanto maior a duração da doença $(p=0,02)$, risco de queda $(p=0,04)$, gravidade da ataxia $(p=0,00)$ e maior dependência funcional para AVD $(p=0,03)$ e $\operatorname{AIVD}(p=0,00)$, pior a $Q V$ no domínio "Capacidade Funcional” com decréscimo de 1,62 ponto para cada ano no tempo de doença. Conclusão: Nesta amostra, o comprometimento da QV em indivíduos com SCA10 foi observado nos domínios "Capacidade Funcional" e "Aspectos Físicos".

Palavras-chave: ataxia espinocerebelar; qualidade de vida; inquéritos e questionários.

Spinocerebellar ataxia type 10 (SCA10) is a neurodegenerative disease with autosomal dominant inheritance ${ }^{1}$. Atrophy of the cerebellum and its afferent and efferent connections $^{2}$ is caused by a pentanucleotide (ATTCT) repeat expansion ranging from 800 to 4,500 repeats in intron 9 of the ATXN10 gene ${ }^{3}$.

\footnotetext{
${ }^{1}$ Universidade Federal do Paraná, Hospital de Clínicas, Programa de Residência Integrada Multiprofissional em Cuidados Hospitalares - Saúde para Adultos e Idosos Curitiba PR, Brasil;

¿Universidade Federal do Paraná, Hospital de Clínicas, Departamento de Medicina Interna, Serviço de Neurologia, Setor de Distúrbios do Movimento, Curitiba PR, Brasil;

${ }^{3}$ Universidade Federal do Paraná, Hospital de Clínicas, Serviço de Estatística, Curitiba PR, Brasil;

«Universidade Federal do Paraná, Departamento de Fisioterapia Preventiva e Reabilitação, Curitiba PR, Brasil;

5Universidade Federal do Paraná, Serviço de Fisioterapia, Curitiba PR, Brasil.

Correspondence: Laudiane Reis Santos; Rua Francisco Torres, 581; 80030-160 Curitiba PR, Brasil; E-mail: reislaudiane@gmail.com

Conflict of interest: There is no conflict of interest to declare.

Received 27 February 2018; Received in final form 13 April 2018; Accepted 07 May 2018.
} 
The characteristic symptoms are gait ataxia, dysarthria, dysphagia, nystagmus and, in some cases, epileptic seizures, reduced cognitive ability and depression ${ }^{4,5}$. In addition, reduced ability to perform activities of daily living (ADL) impairs quality of life (QoL) in individuals with ataxia ${ }^{6}$.

The World Health Organization defines QoL as the individual's perception of their position in society and in relation to their goals, expectations and concerns ${ }^{7}$. A QoL assessment through generic or specific instruments is an important measure of the impact of treatments on health indicators ${ }^{8}$. Health is not merely the absence of disease ${ }^{9}$ and, therefore, should be measured based on QoL ${ }^{10}$. This study aimed to assess the selfperception of QoL and its association with disease duration, severity of ataxia, balance and functional independence.

\section{METHODS}

\section{Participants}

The study population comprised 15 individuals (eight females, seven males) with a diagnosis of SCA10 who were treated in the Ataxia Outpatient Unit. Inclusion criteria were: a) having a positive molecular genetic test for SCA10; b) in the absence of molecular results, having neurological signs characteristic of SCA10 and a family member with a positive genetic test for SCA10; c) absence of dementia; and d) having signed a voluntary informed-consent form.

The study was a prospective, descriptive, cross-sectional study. All the participants were told about the procedures and signed the voluntary informed-consent form. The study was approved by the Committee for Ethics in Research at the Hospital de Clínicas, Federal University of Paraná (HC-UFPR) (CAAE:57853816.0.0000.0096, ref. no.: 1.674.669).

\section{Assessment instruments}

The following instruments, validated in Portuguese, were used: the Medical Outcomes Study 36-Item Short-Form Health Survey Version $2(\text { SF-36 })^{11}$ to assess QoL; the Functional Independence Measure (FIM) ${ }^{12}$ for ADL and the Lawton Instrumental Activities of Daily Living (IADL) scale ${ }^{13}$; the Berg Balance Scale ${ }^{14}$ for balance and fall risk; and the Scale for the Assessment and Rating of Ataxia (SARA) ${ }^{15}$ to rate the severity of the ataxia.

SF-36: This comprises 36 questions. One measures health transition and the others cover eight domains. Scores from 0-100 are assigned to each answer, 0 corresponding to the worst health state and 100 to the best ${ }^{11}$. In our study, we defined a cutoff at 50 points. Scores above this value were classified as "high quality of life", and those below as "low quality of life".

FIM: This instrument provides an objective assessment of an individual's independence in terms of motor and cognitive function. It covers 18 items, and the overall score can vary from 18-126; the lower the final score, the greater the dependence ${ }^{12}$.
Lawton IADL Scale: This assesses an individual's ability to live independently and participate in the community. The scale comprises seven items, and the total score can vary from 7-21. The global score is interpreted as follows: $\leq 5$ - totally dependent; $>5$ and $<21$ - partially dependent; 21 - independent ${ }^{13}$.

Berg Balance Scale: The Berg Balance Scale assesses static and dynamic balance during 14 tasks. A score from 0-4 is assigned to each task, and the maximum score is 56 . Individuals with scores from 41-56 can walk independently (low fall risk), those with scores from 21-40 are able to walk with assistance (medium fall risk) and those with scores from 0 -20 require a wheelchair (high fall risk) ${ }^{14}$.

SARA: This is an eight-item scale for assessing and rating ataxia. The total score ranges from 0 (no ataxia) to 40 (severe ataxia) ${ }^{15}$.

\section{Data collection procedures}

The collection period was from August 2016 to June 2017, during the individual's multidisciplinary routine check-up at the Ataxia Outpatient Unit. The physiotherapy assessment in this outpatient unit included demographic, clinical and laboratory data (age, disease duration, duration of symptoms, number of ATTCT pentanucleotide repeats) and functional data (SARA, Berg, FIM and Lawton IADL scores). After this evaluation, the individuals were invited to participate in the study and were then assessed by one of the researchers using the SF-36 v.2.

\section{Data analysis}

The data were analyzed using Microsoft Office Excel 2013.

To identify the SF-36 domains with the greatest impairment, hypothesis tests were run, in which the mean score in each SF-36 domain was compared with the cutoff (50 points). A $5 \%$ significance level was used. T-tests for equal means with unequal variances were used to confirm the hypotheses.

To confirm the hypothesis that the variables disease duration, Berg, SARA, FIM and Lawton IADL influenced the magnitude of any increase or decrease in QoL in each SF-36 domain, the correlation between each pair of variables was analyzed with ANOVA at a 5\% significance level. When a statistically significant result was obtained, the linear regression equation was determined and the regression line drawn on the scatter plot. The line was fitted using the least squares method, and the linear relationship was identified as either positive or negative. Pearson's correlation coefficient was also calculated for all the SF-36 domains so that the correlation between the variables could be classified as weak, moderate or strong. Descriptive statistics including mean, standard deviation and variance were also calculated.

To analyze the SARA results (which were not obtained for one individual), the technique of replacing the median was used to preserve part of the sample variability and interfere as little as possible with the variable analyzed. 


\section{RESULTS}

The mean age of the 15 individuals with SCA10 in the study was $43.8( \pm 8.3)$ years, mean age of symptom onset 33.1 $( \pm 9.0)$ years and mean disease duration $9.8( \pm 11.2)$ years. The mean score on the Berg Balance Scale was 47.2 ( \pm 12$)$, and four individuals were considered dependent and needed a mobility aid when walking. Of these, three used a walking aid, and one refused to use an aid. The mean SARA score $(\mathrm{n}=14)$ was 11.5 ( \pm 7.3). The mean Lawton IADL score was 20.4 ( \pm 1.8 ); six individuals were independent, three dependent for one item, and six dependent in two to four items. The items for which the most individuals were dependent were "housekeeping", "shopping" and "mode of transportation".
The mean FIM score was 120.3 ( \pm 5.4); seven individuals were independent, five were dependent for one area and three were dependent for two to three areas. The areas with the most dependent individuals were "expression", "social interaction" and "stairs". Considering the means of the scores, most of the study population was independent in ADL and partially dependent in IADL, had a low fall risk (independent balance) and mild ataxia. Demographic, clinical, laboratory and functional data for each individual are shown in Table 1.

Table 2 shows the final scores for each of the eight SF-36 domains for each individual with SCA-10. The scores were calculated according to the formulae in the SF-36 questionnaire. The mean, standard deviation and variance for each domain are also given. Mean scores for

Table 1. Demographic, clinical, laboratory and functional data (SARA, Berg, FIM and Lawton IADL scores) for each individual.

\begin{tabular}{|c|c|c|c|c|c|c|c|c|c|c|c|}
\hline Individual & Gender & Age & Profession & $\begin{array}{c}\text { ATTCT } \\
\text { expansion }\end{array}$ & $\begin{array}{l}\text { Age of onset } \\
\text { of symptoms }\end{array}$ & $\begin{array}{l}\text { Disease } \\
\text { duration }\end{array}$ & Walking aid & $\begin{array}{l}\text { Berg } \\
\text { score }\end{array}$ & $\begin{array}{l}\text { SARA } \\
\text { score }\end{array}$ & $\begin{array}{l}\text { Lawton } \\
\text { IADL score }\end{array}$ & $\begin{array}{l}\text { FIM } \\
\text { score }\end{array}$ \\
\hline 1 & M & 53 & $\mathrm{~N}$ & 1960 & 38 & 15 & Walker & 13 & 25.5 & 16 & 113 \\
\hline 2 & M & 31 & Retired & * & 28 & 3 & No & 55 & $\star \star$ & 19 & 117 \\
\hline 3 & $F$ & 39 & Retired & * & 30 & 9 & No & 52 & 12 & 20 & 118 \\
\hline 4 & M & 38 & Retired & * & 36 & 2 & No & 49 & 7 & 18 & 120 \\
\hline 5 & F & 42 & Disability benefit & 2120 & 37 & 5 & No & 56 & 9 & 20 & 122 \\
\hline 6 & F & 46 & N & 2060 & 44 & 2 & No & 56 & 4 & 21 & 124 \\
\hline 7 & F & 31 & N & 1900 & 27 & 4 & No & 56 & 3.5 & 21 & 124 \\
\hline 8 & M & 55 & Disability benefit & 1980 & 23 & 32 & Wheelchair & 32 & 25.5 & 15 & 117 \\
\hline 9 & F & 50 & $\mathrm{~N}$ & 2160 & 46 & 4 & No & 53 & 12 & 19 & 124 \\
\hline 10 & F & 52 & Pensioner & 2000 & 48 & 4 & No & 47 & 7 & 21 & 125 \\
\hline 11 & M & 34 & Driver & 2560 & 29 & 5 & No & 56 & 3 & 21 & 126 \\
\hline 12 & F & 51 & N & 1800 & 36 & 15 & Walking stick & 47 & 16 & 20 & 108 \\
\hline 13 & M & 53 & Disability benefit & 1980 & 14 & 39 & No & 35 & 18 & 19 & 113 \\
\hline 14 & F & 39 & Administrative assistant & 2304 & 31 & 8 & No & 53 & 11 & 21 & 115 \\
\hline 15 & M & 43 & $\mathrm{~N}$ & 1508 & 30 & 13 & No & 49 & 8.5 & 21 & 124 \\
\hline
\end{tabular}

M: Male; F: Female; N: not working; ATTCT expansion: ATTCT pentanucleotide repeat expansion; *awaiting genetic test; Berg: Berg Balance Scale; SARA: Scale for the Assessment and Rating of Ataxia; **Individual could not be assessed with SARA scale; Lawton IADL: Instrumental Activities of Daily Living (IADL) Scale; FIM: Functional Independence Measure (ADL).

Table 2. Final SF-36 scores for individuals (1 to 15) with SCA10 and mean, standard deviation, variance and p value.

\begin{tabular}{|c|c|c|c|c|c|c|c|c|c|c|c|c|c|c|c|c|c|c|c|c|}
\hline SF-3 & Domain & 1 & 2 & 3 & 4 & 5 & 6 & 7 & 8 & 9 & 10 & 11 & 12 & 13 & 14 & 15 & M & SD & V & -value \\
\hline \multirow{4}{*}{ PC } & Physical functioning & 29 & 39 & 29 & 14 & 84 & 64 & 89 & 9 & 84 & 64 & 99 & 19 & 14 & 24 & 49 & 47.3 & 1.0 & 59.5 & .372 \\
\hline & Role-physical & 55 & 0 & 30 & 0 & 30 & 5 & 30 & 55 & 80 & 55 & 80 & 0 & 0 & 80 & 30 & 35.3 & 30.7 & 941.0 & $\star 0.043$ \\
\hline & Bodily pain & 99 & 99 & 50 & 21 & 63 & 41 & 40 & 99 & 99 & 61 & 99 & 31 & 30 & 99 & 41 & 648 & 308 & 9482 & 0.042 \\
\hline & Gen & 46 & 46 & 56 & 51 & 61 & 51 & 31 & 24 & 51 & 91 & 46 & 84 & 31 & 39 & 66 & 51 & 10 & 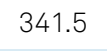 & 1 \\
\hline \multirow{4}{*}{$\mathrm{MC}$} & Role-em & 80 & 0 & 47 & 47 & 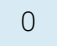 & 0 & 0 & 80 & 80 & 80 & 80 & 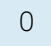 & 0 & . & 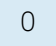 & - 2.0 & . & & 0.052 \\
\hline & Vitality & 74 & 29 & 49 & 19 & 19 & 19 & 39 & 19 & 69 & 79 & 69 & 84 & 54 & 29 & 49 & 46.7 & 23.9 & 571.0 & 0.299 \\
\hline & Social functio & 86 & 24 & 74 & 99 & 49 & 11 & 49 & 99 & 99 & 99 & 99 & 74 & 11 & 11 & 24 & 60.5 & 36.6 & 1336.1 & 0.142 \\
\hline & Mental health & 63 & 51 & 51 & 39 & 27 & 47 & 63 & ( & 99 & 71 & 67 & 7 & 67 & 39 & 4 & 59.3 & 19 & 387.4 & 0.045 \\
\hline
\end{tabular}

SF-36: The Medical Outcomes Study 36- Item Short-Form Health Survey Version 2; PC: Physical Component; MC: Mental Component; M: Mean; SD: Standard Deviation; $\mathrm{V}$ : Variance; Pvalue in relation to a mean of 50 - T-tests for equal means with unequal variances. *Significant; SCA10: Spinocerebellar Ataxia type 10. 
the domains "physical functioning", "role-physical", "roleemotional and "vitality" were below 50, corresponding to poor quality of life. However, to test the significance of these means, the t-test for equal means with unequal variances was used. This revealed that the only domain for which the difference was statistically significant was "role-physical", highlighting the reduced quality of life in this domain in individuals with SCA-10.

When ANOVA was used, and the linear regression model was fitted using least squares, statistically significant relationships at the $5 \%$ level were found between the variables of disease duration, Berg, SARA, FIM, Lawton IADL and the SF-36 domain "physical functioning". The coefficients of the straight lines identified in the linear regression in the Figure indicate whether the relationship between the variables is one of direct proportionality (rising line) or inverse proportionality ( falling line).

Linear regression between "physical functioning" and "disease duration" (A) and between "physical functioning" and the SARA score $(C)$ at the $5 \%$ significance level resulted in fitted regression functions $y=-1.6266 x+64.683$ and $y=-2.867 x$ +80.208 (Figure). These indicate an inversely proportional correlation, i.e., an increase in the SARA score and an increase in disease duration are associated with a lower score in the "physical functioning" domain. A one-point increase in the SARA score and a one-year increase in disease duration can be expected to correspond, respectively, to 2.86-point and 1.62-point decreases in the score in the "physical functioning" domain (Table 3).

Reduced quality of life in the "physical functioning" domain can be expected as disease duration (A) and severity of ataxia (C) increase. The $p$ values used are shown in the Figure.

Linear regression between "physical functioning" and the "Berg" (B), "FIM" (E) and "Lawton" (D) scores at the 5\% significance level resulted in regression functions $\mathrm{y}=1.3767 \mathrm{x}$ 17.738, $\mathrm{y}=8.8807 \mathrm{x}-125.54$ and $\mathrm{y}=4.4935 \mathrm{x}-488.89$ (Figure). These indicate a positive correlation and that the variables are directly proportional, i.e., a decrease in the Berg, FIM and Lawton IADL score will lead to a lower score in the "physical functioning" domain. Decreases of 1.37, 8.88 and 4.49 in the "physical functioning" score can be expected for one-point decreases in the Berg, Lawton IADL and FIM scores, respectively (Table 3).

A reduction in QoL in the domain "physical functioning" is expected as a fall risk (B), functional dependence for ADL (E) and dependence for IADL (D) increase. The p values used are shown in the Figure.

The correlation coefficient (r) varies between 1 and -1 . The closer $r$ is to these values, the stronger the correlation between the variables: $r=0.10$ to 0.30 corresponds to a weak correlation, $r=0.40$ to 0.60 to a moderate correlation and $r=0.70$ to 1 to a strong correlation. The same classification is used for negative values ${ }^{16}$. Pearson's correlation revealed statistically significant results at the 5\% level. Moderate correlations were identified between "physical functioning" and the disease duration, SARA score, Berg score and Lawton IADL score and a strong correlation between "physical functioning" and the FIM. The r values are shown in the Figure.

\section{DISCUSSION}

This study assessed the QoL of individuals with SCA10 and identified impairment in the "role-physical" and "physical functioning" domains. Impairment in the latter was associated with longer disease duration, functional dependence, ataxia severity and fall risk. Although an understanding of how disease affects QoL is important for clinical management, few authors have investigated this relationship in individuals with spinocerebellar ataxias ${ }^{17,18,19}$. The concept of QoL covers physical and psychological health, level of independence, social relationships, environment and beliefs ${ }^{20}$. According to Azevedo et al. ${ }^{21}$, individuals with chronic nervous system diseases have a lower self-perception of QoL than those with diseases in other systems.

Castilhos et al. ${ }^{5}$ showed that Brazil has a considerable number of families with spinocerebellar ataxias and included 359 in a study, most of them in southern Brazil. The

Table 3. SCA10 - Interpretation of the results of the linear regression analysis with least squares method.

\begin{tabular}{|c|c|}
\hline Variable & Interpretation \\
\hline Disease duration vs. Physical functioning & $\begin{array}{l}\text { A 1.62-point* decrease in Physical functioning score can be expected for a one-year } \\
\text { increase in disease duration. }\end{array}$ \\
\hline SARA vs. Physical functioning & $\begin{array}{l}\text { A 2.86-point* decrease in Physical functioning score can be expected for a 1-point increase } \\
\text { in the SARA score. }\end{array}$ \\
\hline Berg vs. Physical functioning & $\begin{array}{c}\text { A 1.37-point* decrease in Physical functioning score can be expected for a 1-point } \\
\text { decrease in the Berg score. }\end{array}$ \\
\hline Lawton vs. Physical functioning & $\begin{array}{l}\text { An 8.88-point* decrease in Physical functioning score can be expected for a 1-point } \\
\text { decrease in the Lawton score. }\end{array}$ \\
\hline FIM vs. Physical functioning & $\begin{array}{l}\text { A 4.49-point* decrease in Physical functioning score can be expected for a 1-point } \\
\text { decrease in the FIM score. }\end{array}$ \\
\hline
\end{tabular}



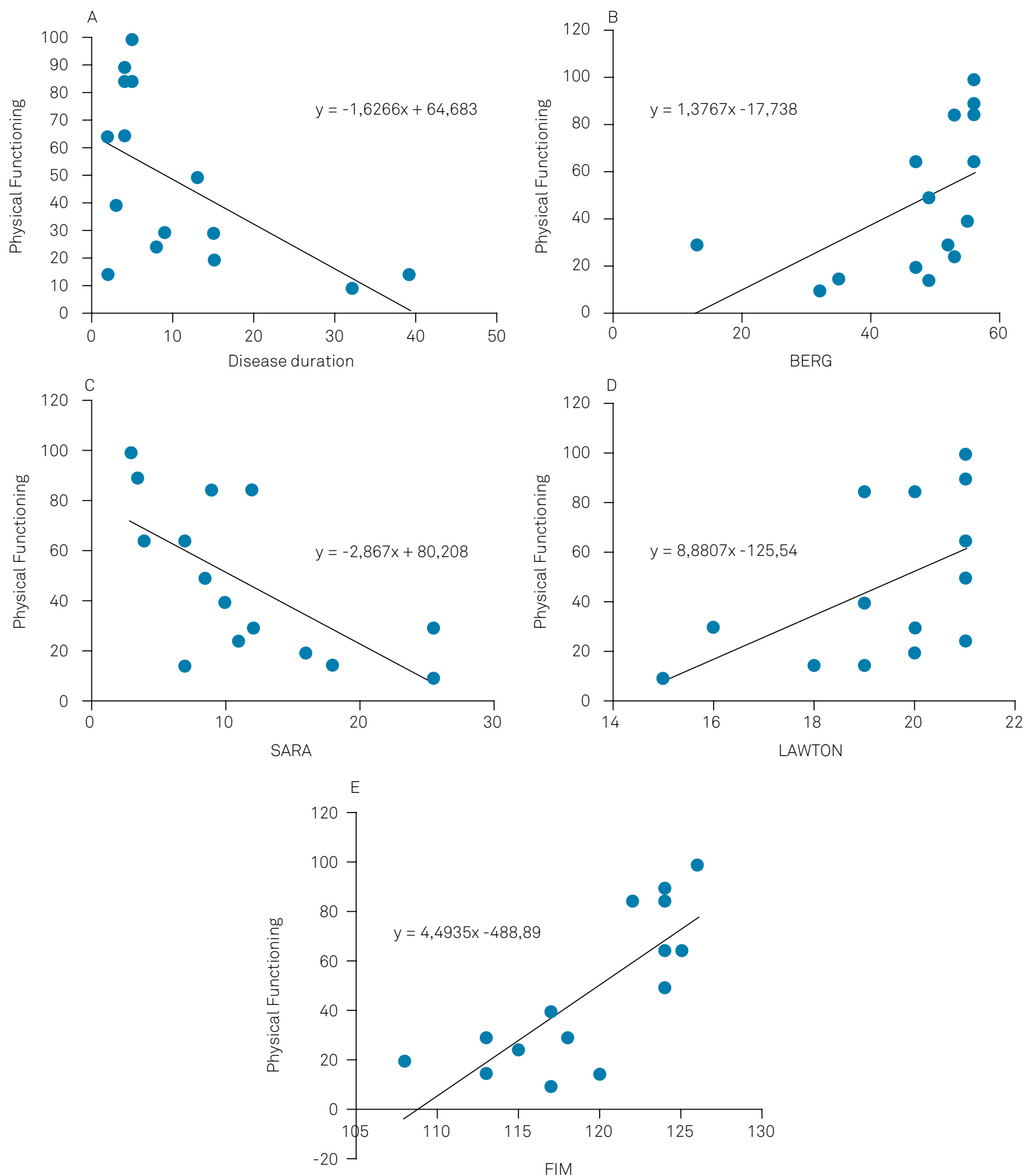

SARA: Scale for the Assessment and Rating of Ataxia; Berg: Berg Balance Scale; Lawton: Lawton Instrumental Activities of Daily Living (IADL) Scale; FIM: Functional Independence Measure (ADL); r: Pearson's coefficient correlation; $p$ : p-values for correlation shown. Statistical findings: Test Anova; Linear regression with least squares method; Pearson's correlation.

Figure. Correlation between the "physical functioning" domain and (A) disease duration, (B) balance (Berg), (C) severity of ataxia (SARA), (D) dependence in instrumental activities of daily living (Lawton) and (E) dependence in basic activities of daily living.

present study assessed individuals with SCA10 in southern Brazil, where this type of SCA is the second most prevalent after SCA3.
The mean age of symptom onset in the study sample was 33 years, corroborating the literature, in which a mean of 33-35 years has been reported ${ }^{5,22}$, and the individuals were young when 
they began to gradually lose their autonomy. Two of them had had the disease for over 30 years. The different series of SCA10 patients in the literature show that the mean disease duration is very variable, with a mean survival of $13-20$ years ${ }^{5,22,23}$.

Although it is a generic instrument, the SF-36 is highly reliable, providing valid data covering the patient's physical and mental health ${ }^{24}$. It has also been used by other authors for individuals with ataxia ${ }^{19,25}$. The "role-physical" domain focuses on how difficulties in performing tasks at work (reflected in, for example, fewer hours spent working) and ADL affect the QoL ${ }^{26}$. The "physical functioning" domain considers the limitations on performing physical activities of different intensities ${ }^{26}$.

The lower scores in the "role-physical" and "physical functioning" domains in this sample corroborate the findings of Sánchez-López et al. ${ }^{19}$. Unlike the present study, which assessed individuals with SCA10, the study by Sánchez-López et al. ${ }^{19}$ assessed individuals with different types of ataxias, allowing the authors to observe the impact of the disease in the "general health", "vitality", "bodily pain" and "social functioning" domains. Tai et al. ${ }^{23}$ observed a reduction in the QoL of individuals with Friedreich's ataxia in all domains of the SF-36. The lower scores in the "role-physical" domain in the present study may be related to the fact that most of the participants were not working, as only two individuals kept their jobs. Work is one of the main activities carried out by adults and, in addition to providing an income, it is associated with satisfaction, social interaction, coexistence and personal fulfilment ${ }^{27}$.

The lower scores in the "physical functioning" domain in the present study were related to longer disease duration, corroborating the findings of Tai et al..$^{23}$. As the symptoms of ataxia progress, the need for help from others increases. In this sample, this was evidenced by the FIM scale for stairs, expression and social interaction. No relationship was observed between the FIM cognitive aspects and the SF-36 mental component, probably because of the sample size, as both the ability to interact socially and to express oneself are considered in the "social role" domain of the SF-36 and are important skills for the individual's well-being.

Dependence in more complex activities of daily living is associated with a lower QoL, considering the "physical functioning" domain. The individuals in this sample were independent for a single item on the Lawton IADL scale (responsibility for their own medications), while activities such as housekeeping, shopping and traveling required help from others. Moreira et al. ${ }^{25}$, when assessing the QoL of individuals with Parkinson's disease, associated dependence on others for ADL with a worse QoL.
In the present study, a greater severity of ataxia was associated with worse QoL in the "physical functioning " domain, corroborating the findings of Graves et al. ${ }^{4}$.These authors assessed individuals with episodic ataxia type 1 and observed that those who had persistent ataxia also had worse ataxia severity and a longer disease duration, as well as difficulties in performing ADL and an increase in falls. In addition, all the SF-36 domains were below normal, particularly the "role-emotional", although the QoL was generally lower in the physical component.

In our study, there was a trend toward a correlation between QoL and the "role-emotional" domain. Ten individuals had a final score below the average of 50 in the "role-emotional" domain, indicating a low QoL, which may have been a result of the mild mood disorder (depression) observed in individuals with SCA10 ${ }^{28}$. The fact that the other five patients had scores of 80 in this domain may explain the lack of correlation with QoL in this sample.

The mean score on the Berg Balance Scale indicated a low fall risk in this sample. Nevertheless, this score was associated with a worse QoL in the "physical functioning" domain. A study by Filippin et al. ${ }^{17}$ assessed balance in individuals with SCA3 and the relationship to all SF-36 domains. They observed that a worse QoL in the "physical functioning" domain was associated with a worse static and dynamic balance and even with a mean Berg score of 41.85, showed a correlation with fall risk. According to Aizawa et al. ${ }^{18}$, signs and symptoms other than ataxia (such as ataxia severity and greater functional impairment) can influence static and dynamic balance.

In a study of 16 individuals with SCA2, Amarante et al..$^{29}$ described how balance, fall risk and ataxia severity evolved over one year of disease. In our study, we found that for every year of disease there was a 1.62-point decrease in the "physical functioning" score, reflecting an increase in disease severity, functional dependence and fall risk.

The small population sample in this study prevented us separating the groups by age, gender, disease duration, age of onset of symptoms, employment status and presence of a caregiver, which may have enabled us to identify significant changes in other SF-36 domains. Further studies with larger population samples are therefore required to confirm our findings.

In conclusion, reduced QoL in individuals with SCA10 in this cohort was associated with the "role-physical" and "physical functioning" domains. Self-perception of QoL was influenced by disease severity, disease duration, balance impairment and level of dependence on others for ADL and IADL.

\section{References}

1. Schöls L, Bauer P, Schmidt T, Schulte T, Riess O.

Autosomal dominant cerebellar ataxias: clinical

features, genetics, and pathogenesis. Lancet

Neurol. 2004 May;3(5):291-304.

https://doi.org/10.1016/S1474-4422(04)00737-9
2. Brazis PW, Biller J, Masdeu JC. Localization in clinical neurology. 4th ed. Philadelphia: Lippincott Williams \& Wilkins; 2001.

3. Teive HA, Munhoz RP, Arruda WO, Raskin S, Werneck LC, Ashizawa T. Spinocerebellar ataxia type 10: a review. Parkinsonism Relat Disord. 2011 Nov;17(9):655-61. https://doi.org/10.1016/j.parkreldis.2011.04.001 
4. Graves TD, Cha YH, Hahn AF, Barohn R, Salajegheh MK, Griggs RC et al. Episodic ataxia type 1: clinical characterization, quality of life and genotype-phenotype correlation.

Brain. 2014 Apr;137(Pt 4):1009-18.

https://doi.org/10.1093/brain/awu012

5. Castilhos RM, Furtado GV, Gheno TC, Schaeffer P, Russo A, Barsottini $\mathrm{O}$ et al. Spinocerebellar ataxias in Brazil;frequencies and modulating effects of related genes. Cerebellum. $2014 \mathrm{Feb} ; 13(1): 17-28$. https://doi.org/10.1007/s12311-013-0510-y

6. Silva BF, Finard SA, Olchik MR. Therapy speech impact in quality of life in patients with MachadoJoseph disease. Rev CEFAC. 2016;18(4):992-1000. https://doi.org/10.1590/1982-0216201618418515

7. The WHOQOL Group. The World Health Organization quality of life assessment (WHOQOL): position paper from the World Health Organization. Soc Sci Med. 1995;41(10):1403-9. https://doi.org/10.1016/0277-9536(95)00112-K

8. Monteiro R, Braile DM, Brandau R, Jatene FB. Focus on quality of life. Rev Bras Cir Cardiovasc. 2010 Oct-Dec;25(4):568-74. https:// doi.org/10.1590/S0102-76382010000400022

9. World Health Organization. Constitution of The World Health Organization. New York, NT: World Health Organization;1946 [accessed 2017 Dec 15]. Available fom: http://apps.who.int/gb/bd/ PDF/bd47/EN/constitution-en.pdf?ua $=1$

10. World Health Organization. Division on Mental Health and Prevention of Substance abuse. WHHOQOL measuring quality of life. Geneva: World Health Organizaton; 1997[accessed on 2017 Dec 15]. Available from: http://www.who.int/mental_health/ media/68.pdf

11. Ciconelli RM, Ferraz MB, Santos W, Meinão I, Quaresma MR. Tradução para a língua portuguesa e validação do questionário genérico de avaliação de qualidade de vida SF-36 (Brasil SF-36). Rev Bras Reumatol. 1999;39(3):143-50.

12. Riberto M, Miyazaki MH, Jucá SSH, Sakamoto H, Pinto PPN, Battistella LR. Validação da Versão Brasileira da Medida de Independência Funcional. ACTAFISIATR.2004;11(2):72-76. http://dx.doi.org/10.5935/0104-7795.20040003

13. Araújo F, Pais-Ribeiro J, Oliveira A, Pinto C, Martins T. Validação da escala de Lawton e Brody numa amostra de idosos não institucionalizados. In: Actas do $7^{\circ}$ Congresso Nacional de Psicologia da Saúde. Lisboa: ISPA; 2008. p. 217-20.

14. Miyamoto ST, Lombardi Junior I, Berg KO, Ramos LR, Natour J. Brazilian version of the Berg balance scale. Braz J Med Biol Res. 2004 Sep;37(9):1411-21. https://doi.org/10.1590/S0100-879×2004000900017

15. Yabe I, Matsushima M, Soma H, Basri R, Sasaki H. Usefulness of the Scale for Assessment and Rating of Ataxia (SARA). J Neurol Sci. 2008;266(1-2):164-6. https://doi.org/10.1016/j.jns.2007.09.021

16. Dancey C, Reidy J. Estatística sem matemática para Psicologia: usando SPSS para Windows. 3nd. Porto Alegre: Artmed; 2006.
17. Filippin NT, Piccinini AM, Libera LBD. Caracterização do equilíbrio, risco de quedas e qualidade de vida em pessoas com doença de Machado-Joseph. Fisioterapia Brasil. 2016;(17):4-9.

18. Aizawa CY, Pedroso JL, Braga-Neto P, Callegari MR, Barsottini OG. Patients with autosomal dominant spinocerebellar ataxia have more risk of falls, important balance impairment, and decreased ability to function. Arq Neuropsiquiatr. 2013 Aug;71(8):508-11. https://doi.org/10.1590/0004-282X20130094

19. Sánchez-López CR, Perestelo-Pérez L, Escobar A, López-Bastida J, Serrano-Aguilar P. Health-related quality of life in patients with spinocerebellar ataxia. Neurologia. 2017 Apr;32(3):143-51. https://doi.org/10.1016/j.nrl.2015.09.002

20. Landeiro GMB, Pedrozo CCR, Gomes MJ, de Araújo Oliveira E. Revisão sistemática dos estudos sobre qualidade de vida indexados na base de dados SciELO. Cienc Saúde Coletiva. 2011;16(10):4257-66. https://dx.doi.org/10.1590/S1413-81232011001100031

21. Azevedo ALS, Silva RA, Tomasi E, Quevedo LA. Doenças crônicas e qualidade de vida na atenção primária à saúde. Cad.Saúde Pública.2013;29(9):1774-1782. http://dx.doi.org/10.1590/0102-311X00134812

22. Teive HA, Munhoz RP, Arruda WO, Lopes-Cendes I, Raskin S, Werneck LC, et al. Spinocerebellar ataxias: genotype-phenotype correlations in 104 Brazilian families. Clinics (São Paulo). 2012;67(5):443-9. https://doi.org/10.6061/clinics/2012(05)07

23. Tai G, Yiu EM, Corben LA, Delatycki MB. A longitudinal study of the Friedreich Ataxia Impact Scale. J Neurol Sci. 2015 May;352(1-2):53-7. https://doi.org/10.1016/j.jns.2015.03.024

24. Laguardia J, Campos MR, Travassos C, Najar AL, Anjos LA, Vasconcellos MM. Dados normativos brasileiros do questionário Short Form-36 versão 2. Rev Bras Epidemiol. 2013;16(4):889-97. https://doi.org/10.1590/S1415-790X2013000400009

25. Moreira RC, Zonta MB, Araújo AP, Israel VL, Teive HA. Quality of life in Parkinson's disease patients: progression markers of mild to moderate stages. Arq Neuropsiquiatr. 2017 Aug;75(8):497-502. https://doi.org/10.1590/0004-282×20170091

26. Ware J, Snow KK, Kosinski M, Gandek B. SF-36 Health survey: manual and interpretation guide. Boston: New England Medical Center; 1993 [accessed on 2017 Dec 15]. Available from: https:// www.researchgate.net/publication/313050850_SF36_Health_ Survey_Manual_Interpretation_Guide

27. Marqueze EC, Moreno CRC. Satisfação no trabalho: uma breve revisão. Rev Bras Saúde Ocupacional. 2005;30(112):69-79. https://doi.org/10.1590/S0303-76572005000200007

28. Moro A, Teive HA. Cognitive impairment in Spinocerebellar ataxia type 10. Dement Neuropsychol. 2016 Oct-Dec;10(4):310-4. https://doi.org/10.1590/s1980-5764-2016dn1004009

29. Amarante TR, Takeda SY, Teive HA, Zonta MB. Impact of disease duration on functional status of patients with spinocerebellar ataxia type 2. Arq Neuropsiquiatr. $2017 \mathrm{Nov;75(11):773-7.}$ https://doi.org/10.1590/0004-282×20170146 